\title{
PENERAPAN PERATURAN DENGAN MENGGUNAKAN SIMULASI PARAMETRIK PADA BANGUNAN DAN LINGKUNGAN PERMUKIMAN KAMPUNG SILIWANGI BANDUNG
}

\author{
Lilian Setiawan $^{1}$, Rumiati Rosaline Tobing ${ }^{2}$ \\ Universitas Katolik Parahyangan \\ ${ }^{1}$ setiawan.lilian@ymail.com, ${ }^{2}$ rumitob@yahoo.com
}

\begin{abstract}
Abstrak: Kota Bandung mengalami perkembangan pembangunan fisik secara pesat. Proses pertumbuhan dan perkembangan kota sangat ditentukan oleh kepentingan strategis pemerintah kota itu sendiri. Oleh sebab itu, pemerintah mengatur arah pertumbuhan kota melalui pembentukan seperangkat peraturan. Namun, kondisi pengaturan dan penataan pembangunan fisik saat ini cukup mengkhawatirkan. Proses yang diterapkan banyak yang tidak sejalan dengan peraturan yang sudah ada, pemanfaatan lahan permukiman tumbuh secara ilegal sehingga kualitas lingkungan fisik pun menurun. Kenyamanan fisik di sebuah kawasan juga berkaitan erat dengan kondisi alam dan lingkungannya. Seperti halnya Sungai Cikapundung yang keberadaannya tidak lagi diperhatikan, terlihat pada bangunan tepi sungai khususnya di Kampung Siliwangi yang semakin liar dan tumbuh organik. Tujuan dari penelitian ini diharapkan dapat menemukenali penataan fisik lingkungan dan tata bangunan kawasan permukiman tepi Sungai Cikapundung Bandung serta pengaruhnya pada penerapan peraturan. Metode yang digunakan adalah 1) Pendekatan kuantitatif pada tahap pengumpulan data dan analisis awal dengan bantuan permodelan teknik simulasi parametrik menggunakan software Rhinoceros Grasshopper; 2) Pendekatan kualitatif dalam menarik kesimpulan yang berkaitan dengan kecenderungan atau prediksi bentuk massa bangunan dan ruang yang terjadi dibandingkan dengan kondisi eksisting. Analisis dilakukan berdasarkan studi peraturan yang berlaku meliputi Koefisien Dasar Bangunan (KDB), Koefisien Lantai Bangunan (KLB), dan Garis Sempadan Sungai, kemudian diaplikasikan pada simulasi bentuk tata bangunan dan lingkungan kawasan, serta mengidentifikasikan perilaku penghuni fisik spasial. Penelitian ini diharapkan dapat menjadi sebuah pedoman atau strategi perencanaan, penataan, dan pengembangan arsitektur baik bentuk massa bangunan maupun ruang fisik di kawasan permukiman tepi sungai.
\end{abstract}

Kata kunci : Peraturan Bangunan, Simulasi Parametrik, Permukiman, Tepi Sungai

\begin{abstract}
The city of Bandung had a rapid development. The growth and development process of the city is largely determined by the strategy of the government itself. Therefore, the government regulates the direction of urban growth through the formation of regulations. However, the current condition of regulations and arrangement of development are quite worrying. The process applied is not in line with regulations, the quality of the environment decreases because of the illegally grown land use of settlements Covenience in an area is also closely related to the conditions of nature environment. Like the existence of Cikapundung river which is no longer considered. It can be seen in riverside housing at Kampung Siliwangi that increasingly wild and growing organically. The purpose of this study is to identify the physical arrangement of the environment and buildings in the Cikapundung riverside settlement Bandung and its influence on the application of regulations. The method used is 1) A quantitative approach at the stage of data collection and analysis with parametric simulation technique modeling, using Rhinoceros Grasshopper software; 2) A qualitative approach in forming conclusions relating to the prediction of the building mass compared to the existing conditions. Analysis was carried out based on applicable regulatory studies including Building Coverage Ratio (BCR), Floor Average Ratio (FAR), and River Border Line, then applied to the simulation of building shapes, and identified behavior of the inhabitants. This research is expected to be a guide to the strategy of planning, structuring, and developing architcture especially the building form in riverside settlements.
\end{abstract}

Keywords : Building Regulations, Parametric Simulation, Riverside, Settlement 


\section{PENDAHULUAN}

\subsection{LATAR BELAKANG}

Proses pertumbuhan dan perkembangan kota sangat ditentukan oleh kepentingan strategis pemerintah kota itu sendiri. Pemerintah kota mengatur arah pertumbuhan dan perkembangan kota melalui pembentukan seperangkat peraturan. Keberadaan peraturan adalah untuk mengatur dan membina penyelenggaraan bangunan gedung demi kelangsungan dan peningkatan kehidupan serta penghidupan masyarakat (UU No. 28 Tahun 2002 Tentang Bangunan Gedung). Saat ini Kota Bandung mengalami perkembangan pembangunan fisik secara pesat yang dipengaruhi oleh pertambahan penduduk dan berakibat pada perubahan fisik dan penggunaan lahan. Pengaruh tersebut dapat bergerak menuju ke arah yang lebih baik, tetapi dapat pula mengakibatkan terjadinya penurunan efisiensi dan efektivitas struktur dan bentuk kota dalam mendukung kegiatan hidup masyarakat kota.

Perkembangan pembangunan fisik suatu kawasan perkotaan sangat erat hubungannya dengan kondisi alam dan lingkungan di sekitarnya termasuk upaya penataan ruang dalam seluruh bangunan yang ada, terutama untuk permukiman Kampung Siliwangi di sepanjang tepi Sungai Cikapundung Bandung. Penerapan kualitas hunian yang baik akan lebih efisien bila dikaitkan dengan aspek perijinan dan peraturan dalam mendirikan bangunan tersebut. Namun dalam pelaksanaannya dirasakan masih dihadapkan pada berbagai kendala. Tekanan kebutuhan mengakibatkan berbagai perubahan bentuk arsitektur yang terjadi tanpa mampu dikendalikan oleh peraturan. Peraturan pertanahan tentang kepemilikan, konversi lahan, penggabungan maupun pemindahan lahan didasarkan pada bentuk bangunan.

\subsection{TUJUAN DAN MANFAAT PENELITIAN}

Berdasarkan pengamatan tersebut, penelitian dilakukan untuk menemukenali kecenderungan atau gambaran pembentukan massa bangunan dan ruang di permukiman Kampung Siliwangi tepi Sungai Cikapundung serta pengaruhnya pada penerapan peraturan. Manfaat penelitian bagi ranah pemerintah adalah menjadi sebuah masukan dalam penyusunan standar teknis penataan kawasan tepi sungai serta rencana tata bangunan dan lingkungan; bagi ranah praktisi adalah menjadi pedoman strategi perancangan, penataan, dan pengembangan arsitektur baik bentuk massa bangunan maupun ruang fisik lingkungan pada kawasan permukiman tepi sungai.

\section{KASUS STUDI DAN METODE PENELITIAN}

\subsection{KASUS STUDI}

Dari hasil data Badan Pusat Statistik Kota Bandung mengenai jumlah rumah tangga menurut kecamatan tahun 2017, terdapat lima kecamatan yang memiliki jumlah Rumah Tangga (Kepala Keluarga) terbesar dan terpadat, salah satunya adalah Kecamatan Coblong. Berdasarkan kriteria tersebut diambil objek studi yang berada pada Kecamatan Coblong, Kelurahan Cipaganti, yaitu : Kampung Siliwangi, dengan batas wilayah di sebelah utara Jalan Siliwangi; di sebelah barat Jalan Cihampelas; di sebelah selatan Gg. Cihampelas Bawah; dan di sebelah timur Kelurahan Lebak Siliwangi dan Kebun Binatang. Lokasi unit amatan difokuskan pada permukiman di sepanjang tepi Sungai Cikapundung, mencakup 4 RW antara lain RW 01, RW 02, RW 03, dan RW 04 dengan jumlah 72 tapak bangunan. 


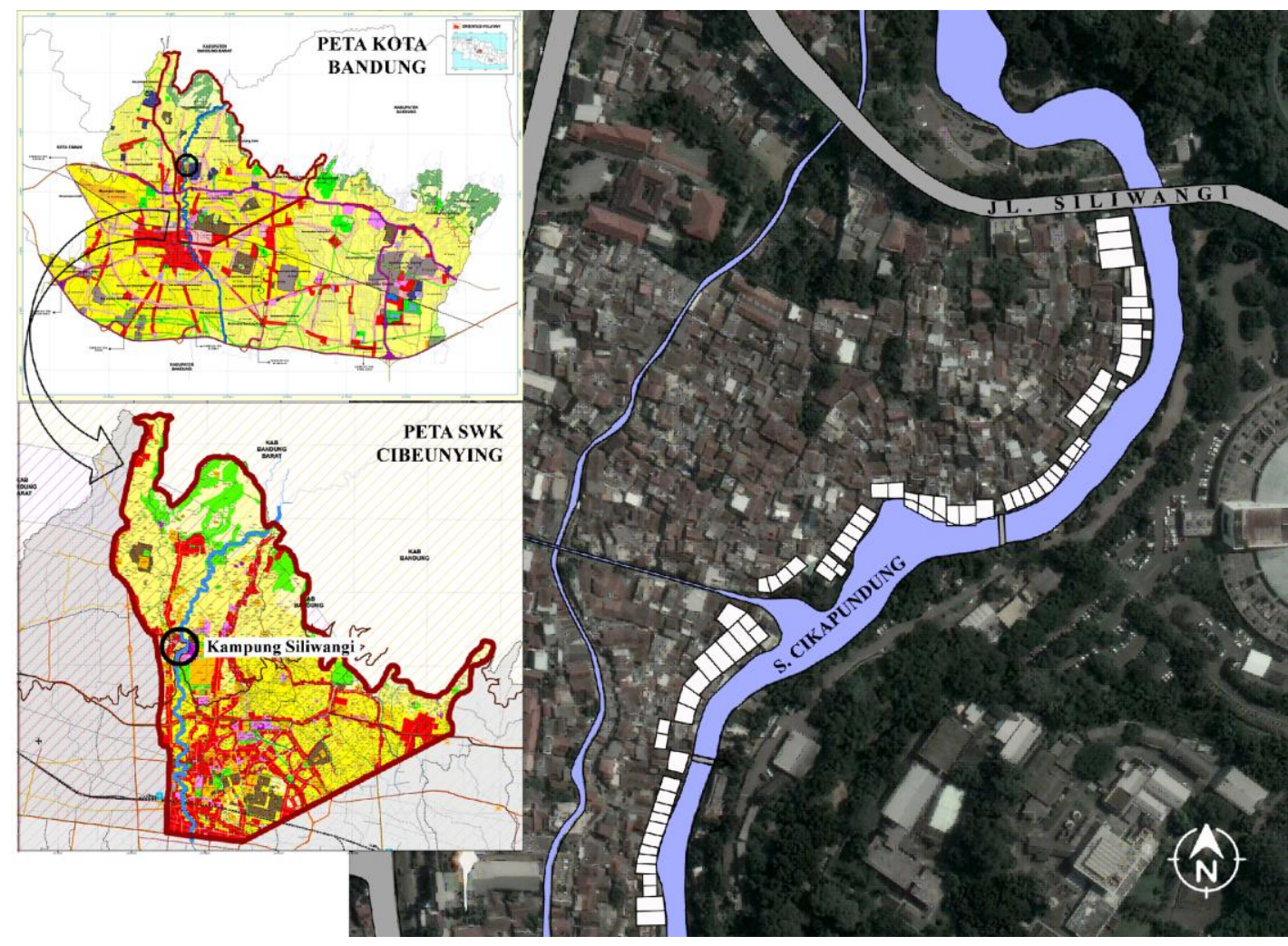

Gambar 1 : Peta Permukiman Kampung Siliwangi

PETA RENCANA POLA RUANG SWK CIBEUNYING

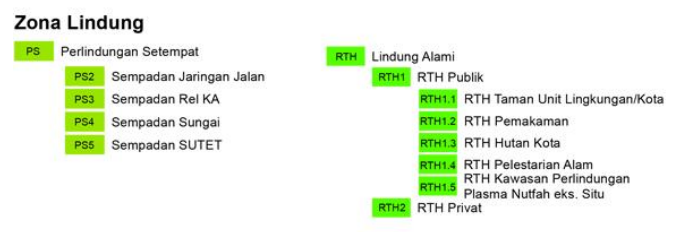

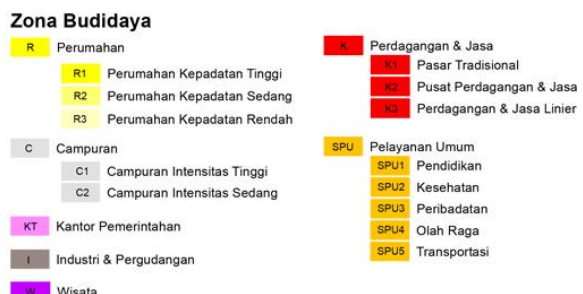
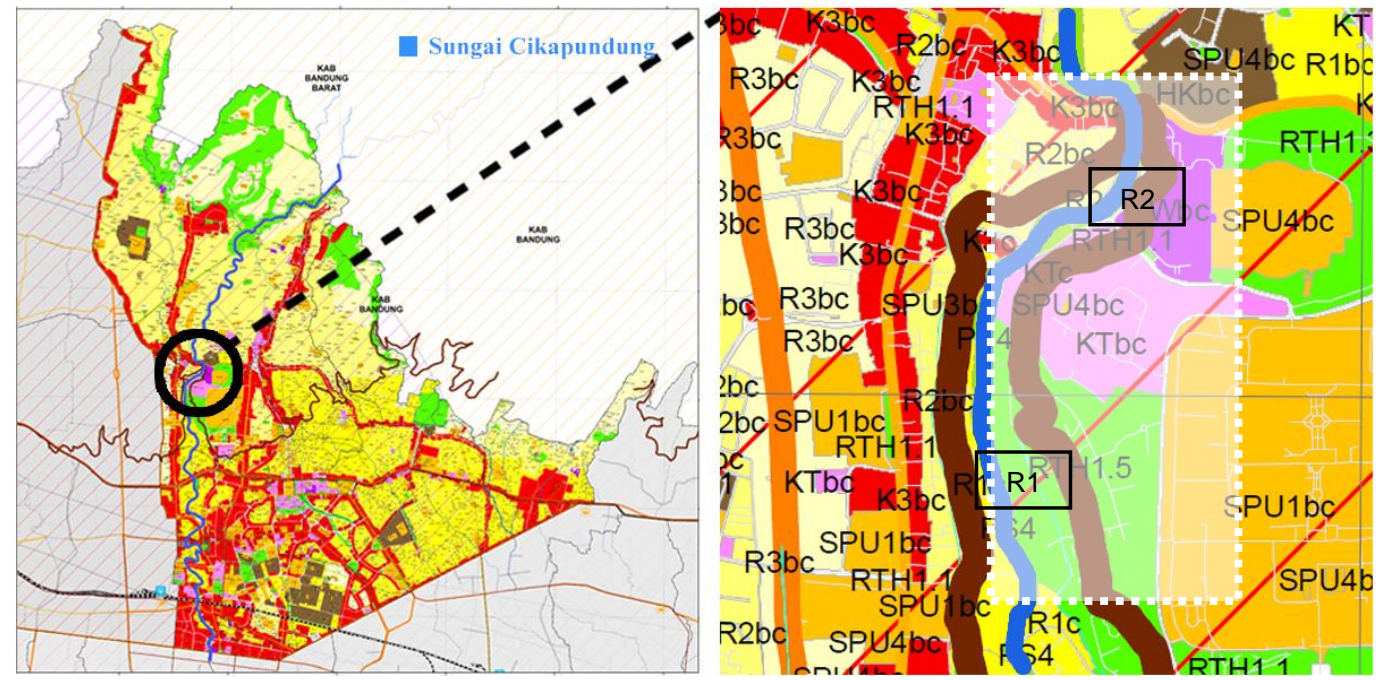

Gambar 2 : Peta Rencana Pengaturan Pola Ruang dalam KDB dan KLB 
Berdasarkan Rencana Detail Tata Ruang Kota dan Peraturan Zonasi Kota Bandung Tahun 2015-2035, peraturan pembangunan yang berlaku di kawasan tepi Sungai Cikapundung khususnya Kampung Siliwangi meliputi Koefisien Dasar Bangunan (KDB) maksimum, Koefisien Lantai Bangunan (KLB) maksimum, dan garis sempadan sungai. Area sempadan sungai bertanggul di kawasan perkotaan untuk Kampung Siliwangi paling sedikit berjarak 3 meter dari tepi luar kaki tanggul sepanjang alur sungai (Permen PUPR RI No. 28 Tahun 2015).

Tabel 1 : RDTR Ketentuan Intensitas Pemanfaatan Ruang

\begin{tabular}{ccccc}
\hline KODE & ZONA & Sub Zona & KDB Maksimum & KLB Maksimum \\
\cline { 4 - 5 } ZONA & Fungsi Jalan & $\begin{array}{c}\text { Fungsi Jalan } \\
\text { (lokal lingk.) }\end{array}$ & (lokal lingk.) \\
\hline R. 1 & $\begin{array}{c}\text { Perumahan } \\
\text { Kepadatan Tinggi }\end{array}$ & $\begin{array}{c}\text { Landed (luas persil } \\
\left.<150 \mathrm{~m}^{2}\right)\end{array}$ & $60 \%$ & 1,2 \\
\hline R. 2 & $\begin{array}{c}\text { Perumahan } \\
\text { Kepadatan Sedang }\end{array}$ & $\begin{array}{c}\text { Landed (luas persil } \\
\left.150-350 \mathrm{~m}^{2}\right)\end{array}$ & $60 \%$ & 1,2 \\
\hline
\end{tabular}

\subsection{METODE PENELITIAN}

Dalam proses pengumpulan data dan analisisnya, digunakan dua pendekatan yaitu pendekatan kuantitatif dan kualitatif. Metode kuantitatif digunakan dalam tahap pengumpulan data dan analisis awal. Untuk memperoleh gambaran (prediksi) tentang peluang yang mungkin terjadi berdasarkan data eksisting tapak dan bangunan dikaitkan dengan regulasi yang berlaku, dilakukan suatu permodelan teknik simulasi parametrik. Parametric design tools telah menjadi alat bantu yang semakin banyak digunakan dalam praktek desain arsitektur dan pendidikan kontemporer. Simulasi parametrik adalah proses pencarian bentuk yang didasarkan pada beberapa parameter.

Aplikasi komputer yang digunakan adalah software Rhinoceros Grasshopper dari Galapagos. Software digunakan untuk memperlihatkan prediksi bentuk massa bangunan yang akan terjadi dengan input data parameter peraturan yang berlaku pada objek studi. Kemudian dilanjutkan dengan proses pemetaan kawasan pada Rhinoceros dan aplikasi parameter pada setiap tapak dalam algoritma Grasshopper. Proses ini akan menghasilkan gambaran bentuk dua dimensi berupa tampak atas (site plan) dan tiga dimensi berupa perspektif bangunan di setiap tapak.

Metode lain yang digunakan dengan metode kualitatif, dengan cara deskriptif analisis yaitu mendeskripsikan perilaku penduduk masyarakat tepi sungai secara sosial dan ekonomi. Bentuk massa dan ruang yang terjadi pada objek studi diidentifikasikan bagaimana pengaruh penerapan peraturan di dalamnya. Proses analisis secara kualitatif dilakukan setelah proses simulasi selesai, selanjutnya dikembangkan dengan pewarnaan yang dibedakan berdasarkan jumlah kehilangan luasan dalam tapak. Tahap ini adalah cara untuk menarik kesimpulan yang berkaitan dengan kecenderungan pembentukan tata bangunan dan lingkungan di kawasan permukiman tepi sungai. 


\section{HASIL DAN TEMUAN}

Kondisi yang berhimpitan dengan tetangga dan batas sungai memperlihatkan bahwa hunian tidak menerapkan peraturan secara benar. Simulasi dibedakan berdasarkan jumlah kehilangan luasan sebuah tapak, warna hijau untuk bangunan yang masih ideal dan layak huni karena hanya sedikit kehilangan luasan yaitu antara $0.00 \%-24.99 \%$, warna kuning untuk kehilangan luasan antara $25.00 \%-49.99 \%$, warna jingga untuk kehilangan luasan antara 50.00 \%-74.99 $\%$, dan warna merah apabila setelah aplikasi peraturan mengalami banyak kehilangan luasan antara $75.00 \%-100.00 \%$.

Berdasarkan simulasi dengan menggunakan parameter regulasi yang telah ditentukan, ditemukan bahwa efektivitas lahan terbangun Kampung Siliwangi masih cukup baik karena tidak banyak kehilangan luasan. Meskipun ada sejumlah kecil tapak ada yang tidak memungkinkan dibangun dengan kehilangan luas antara $75.00 \%-100.00 \%$ (warna merah). Luas ini diperhitungkan sesuai dengan luas seharusnya yang dapat dibangun apabila parameter KDB dan KLB digunakan secara maksimum. Pada simulasi juga terlihat adanya luas efektif yang cenderung terlalu kecil.
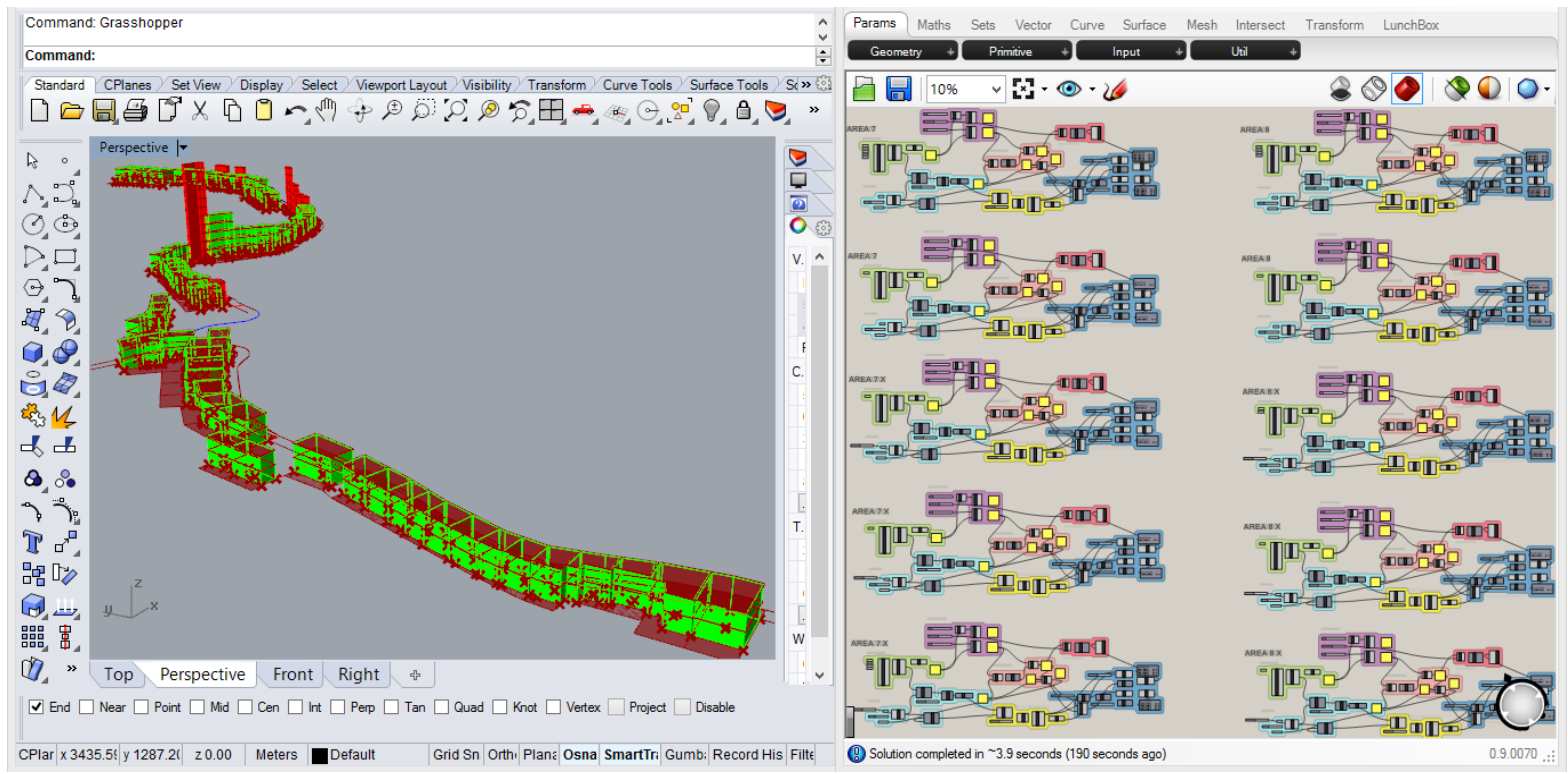

Gambar 3 : Hasil Simulasi Rhinoceros Grasshopper 


\section{SIMULASI KAMPUNG SILIWANG UNIT AMATAN 1}

PARAMETER PERATURAN

$\begin{array}{ll}\text { KDB (MAX) } & : 60 \% \\ \text { KLB (MAX) } & : 1,2 \\ \text { GSS } & : 3 \mathrm{M}\end{array}$

GSS

: $3 \mathrm{M}$

* SELISIH ANTARA LUAS TIDAK EFEKTIF (KDB TERHADAP KLB) SETELAH TERPOTONG GARIS SEMPADAN SUNGAI MENGHASILKAN JUMLAH (\%) KEHILANGAN LUASAN

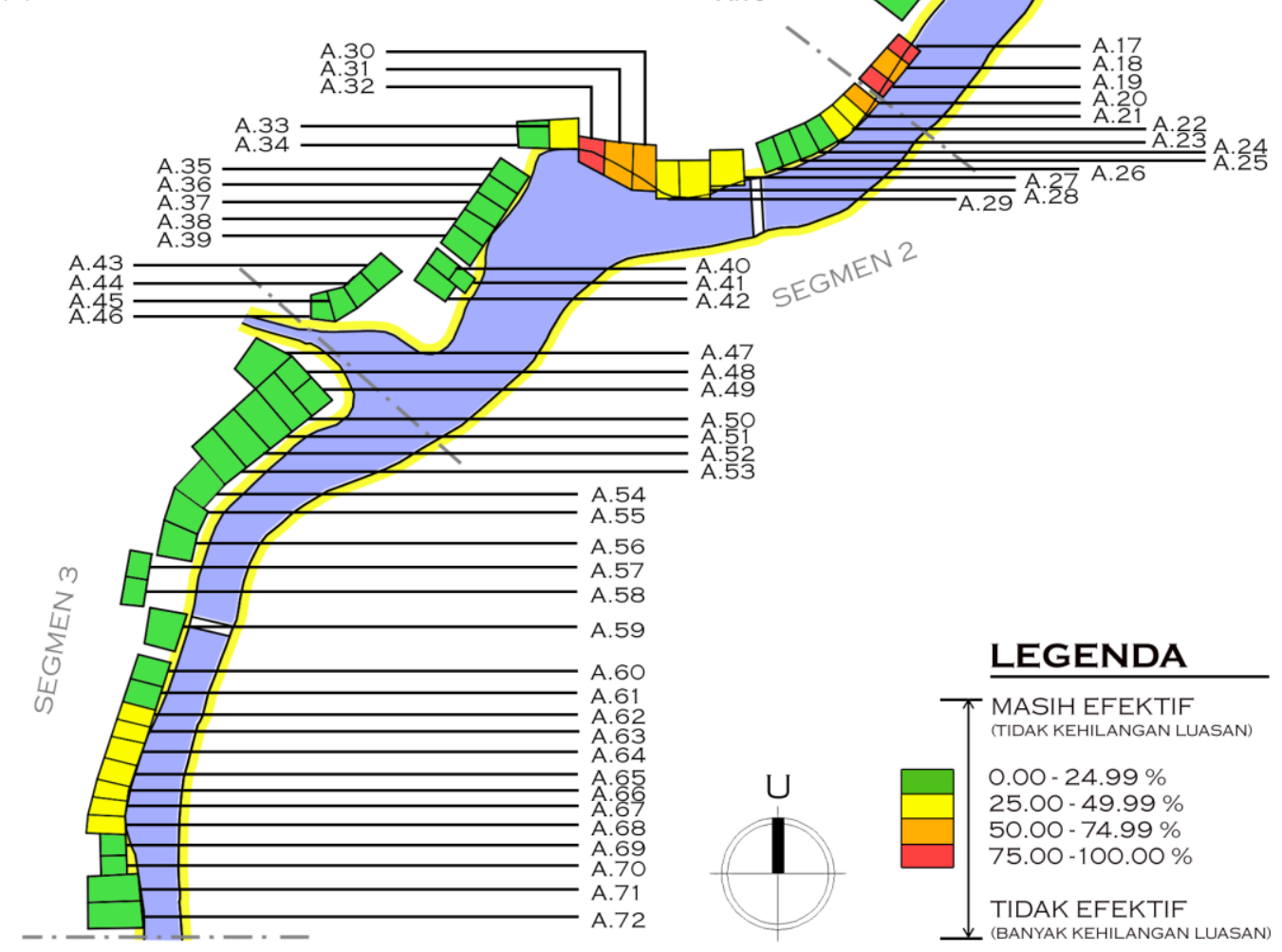

Gambar 4 : Penggambaran Ulang Hasil Simulasi dengan Teknik Pewarnaan

Tabel 2 : Tabel Analisis Luas Terbangun Sesuai Regulasi Berlaku

\begin{tabular}{|c|c|c|c|c|c|c|}
\hline \multirow{2}{*}{$\begin{array}{c}\text { Kode } \\
\text { Kavling }\end{array}$} & \multirow{2}{*}{$\begin{array}{c}\text { Lebar } \\
\text { Muka } \\
(\mathbf{m})\end{array}$} & \multirow{2}{*}{$\begin{array}{c}\text { Eksisting } \\
\text { Jumlah } \\
\text { Lantai }\end{array}$} & \multirow{2}{*}{$\begin{array}{c}\begin{array}{c}\text { Hasil } \\
\text { Simulasi }\end{array} \\
\text { Jumlah } \\
\text { Lantai }\end{array}$} & \multirow{2}{*}{$\begin{array}{c}\text { Eksisting } \\
\text { Luas } \\
\text { Bangunan }\left(\mathbf{m}^{2}\right)\end{array}$} & \multirow{2}{*}{$\begin{array}{c}\text { Hasil } \\
\text { Simulasi } \\
\text { Luas } \\
\text { Bangunan }\left(\mathbf{m}^{2}\right)\end{array}$} & \multirow{2}{*}{$\begin{array}{l}\text { Kehilangan } \\
\text { Luasan (\%) }\end{array}$} \\
\hline & & & & & & \\
\hline A. 1 & 6,7 & 1 Lantai & 2 Lantai & 113,23 & 113,23 & 0,00 \\
\hline A. 2 & 8,1 & 1 Lantai & 2 Lantai & 136,89 & 136,89 & 0,00 \\
\hline A. 3 & 8,8 & 3 Lantai & 2 Lantai & 141,68 & 141,68 & 0,00 \\
\hline A. 4 & 14,5 & 2 Lantai & 2 Lantai & 89,9 & 58 & 35,48 \\
\hline A.5 & 5 & 2 Lantai & 2 Lantai & 63,5 & 54 & 14,96 \\
\hline A. 6 & 5,5 & 1 Lantai & 4 Lantai & 27,5 & 11 & 60,00 \\
\hline A.7 & 5,3 & 1 Lantai & 2 Lantai & 53,53 & 53,53 & 0,00 \\
\hline A. 8 & 4,9 & 1 Lantai & 4 Lantai & 24,5 & 6,86 & 72,00 \\
\hline A. 9 & 7,1 & 1 Lantai & 2 Lantai & 76,68 & 76,68 & 0,00 \\
\hline A. 10 & 8,4 & 1 Lantai & 2 Lantai & 84,84 & 84,84 & 0,00 \\
\hline A. 11 & 11 & 1 Lantai & 2 Lantai & 113,3 & 113,3 & 0,00 \\
\hline
\end{tabular}




\begin{tabular}{|c|c|c|c|c|c|c|}
\hline A.12 & 4 & 1 Lantai & 3 Lantai & 16,8 & 9,6 & 42,86 \\
\hline A.13 & 8,5 & 1 Lantai & 2 Lantai & 73,1 & 73,1 & 0,00 \\
\hline A.14 & 6,6 & 1 Lantai & 2 Lantai & 49,5 & 49,5 & 0,00 \\
\hline A. 15 & 6,8 & 1 Lantai & 2 Lantai & 59,16 & 59,16 & 0,00 \\
\hline A.16 & 6,8 & 1 Lantai & 2 Lantai & 59,16 & 59,16 & 0,00 \\
\hline A.17 & 4 & 1 Lantai & 6 Lantai & 27,2 & 3,2 & 88,24 \\
\hline A. 18 & 6 & 3 Lantai & 4 Lantai & 42 & 10,8 & 74,29 \\
\hline A.19 & 4 & 2 Lantai & 3 Lantai & 29,6 & 7,2 & 75,68 \\
\hline A. 20 & 4,1 & 2 Lantai & 3 Lantai & 31,98 & 10,66 & 66,67 \\
\hline A. 21 & 4,1 & 2 Lantai & 2 Lantai & 34,03 & 21,32 & 37,35 \\
\hline A. 22 & 5 & 2 Lantai & 2 Lantai & 41,5 & 29 & 30,12 \\
\hline A. 23 & 5,1 & 2 Lantai & 2 Lantai & 42,33 & 32,64 & 22,89 \\
\hline A. 24 & 4,8 & 1 Lantai & 2 Lantai & 38,88 & 31,68 & 18,52 \\
\hline A. 25 & 4,4 & 1 Lantai & 2 Lantai & 35,64 & 29,48 & 17,28 \\
\hline A. 26 & 4,4 & 1 Lantai & 2 Lantai & 35,64 & 27,28 & 23,46 \\
\hline A. 27 & 8,8 & 2 Lantai & 2 Lantai & 80,96 & 59,84 & 26,09 \\
\hline A. 28 & 7,6 & 2 Lantai & 2 Lantai & \begin{tabular}{|l|l|}
75,24 \\
\end{tabular} & 49,4 & 34,34 \\
\hline A.29 & 5,7 & 2 Lantai & 2 Lantai & $\begin{array}{l}56,43 \\
\end{array}$ & $\begin{array}{l}30,78 \\
\end{array}$ & 45,45 \\
\hline A.30 & 5,9 & 2 Lantai & 3 Lantai & 71,98 & 31,86 & 55,74 \\
\hline A.31 & 7,1 & 2 Lantai & 5 Lantai & \begin{tabular}{|l|l|}
78,81 \\
\end{tabular} & 23,43 & 70,27 \\
\hline A. 32 & 6,6 & 2 Lantai & 11 Lantai & 52,14 & 3,96 & 92,41 \\
\hline A. 33 & 7,3 & 1 Lantai & 2 Lantai & 51,83 & 33,58 & 35,21 \\
\hline A.34 & 7,8 & 1 Lantai & 2 Lantai & 49,14 & 46,02 & 6,35 \\
\hline A.35 & 4,9 & 1 Lantai & 2 Lantai & 42,63 & 35,28 & 17,24 \\
\hline A.36 & 4,8 & 1 Lantai & 2 Lantai & 41,76 & 36 & 13,79 \\
\hline A.37 & 4,8 & 1 Lantai & 2 Lantai & 43,68 & 33,12 & 24,18 \\
\hline A.38 & 5,4 & 1 Lantai & 2 Lantai & 49,68 & 37,29 & 24,94 \\
\hline A.39 & 7,8 & 1 Lantai & 2 Lantai & $\begin{array}{l}75,66 \\
\end{array}$ & 69,42 & 8,25 \\
\hline A. 40 & 4 & 1 Lantai & 2 Lantai & 20 & 15,2 & 24,00 \\
\hline A.41 & 4 & 2 Lantai & 2 Lantai & 28 & 28 & 0,00 \\
\hline A. 42 & 4,4 & 2 Lantai & 2 Lantai & 42,68 & 42,68 & 0,00 \\
\hline A. 43 & 7,8 & 2 Lantai & 2 Lantai & 53,82 & 53,82 & 0,00 \\
\hline A. 44 & 6,7 & 2 Lantai & 2 Lantai & 43,55 & 43,55 & 0,00 \\
\hline A. 45 & 6,3 & 2 Lantai & 2 Lantai & 39,06 & 39,06 & 0,00 \\
\hline A. 46 & 5,7 & 2 Lantai & 2 Lantai & 38,76 & 38,76 & 0,00 \\
\hline A. 47 & 10,3 & 2 Lantai & 2 Lantai & 100,94 & 100,94 & 0,00 \\
\hline A. 48 & 7,2 & 2 Lantai & 2 Lantai & 41,76 & 41,76 & 0,00 \\
\hline A.49 & 6,4 & 2 Lantai & 2 Lantai & 48,64 & 48,64 & 0,00 \\
\hline A.50 & 6,1 & 2 Lantai & 2 Lantai & 92,11 & 92,11 & 0,00 \\
\hline A. 51 & 7 & 2 Lantai & 2 Lantai & 101,5 & 101,5 & 0,00 \\
\hline A. 52 & 7,6 & 2 Lantai & 2 Lantai & 105,64 & 105,64 & 0,00 \\
\hline A.53 & 6,9 & 2 Lantai & 2 Lantai & 91,77 & 91,77 & 0,00 \\
\hline A.54 & 8,1 & 3 Lantai & 2 Lantai & 72,9 & 72,9 & 0,00 \\
\hline A.55 & 6,1 & 3 Lantai & 2 Lantai & 56,73 & 56,73 & 0,00 \\
\hline A.56 & 6,9 & 1 Lantai & 2 Lantai & 62,79 & 62,79 & 0,00 \\
\hline A.57 & 6,5 & 1 Lantai & 2 Lantai & 33,8 & 33,8 & 0,00 \\
\hline A.58 & 6,7 & 1 Lantai & 2 Lantai & 34,84 & 34,84 & 0,00 \\
\hline A.59 & 10,2 & 2 Lantai & 2 Lantai & 80,58 & 76,5 & 5,06 \\
\hline A. 60 & 6,3 & 2 Lantai & 2 Lantai & 53,55 & 47,25 & 11,76 \\
\hline A.61 & 6 & 1 Lantai & 2 Lantai & 51 & 43,2 & 15,29 \\
\hline A.62 & 4,1 & 2 Lantai & 2 Lantai & 35,26 & 22,96 & 34,88 \\
\hline A.63 & 3,8 & 2 Lantai & 2 Lantai & 32,68 & 21,28 & 34,88 \\
\hline A.64 & 5,8 & 2 Lantai & 2 Lantai & 49,88 & 32,48 & 34,88 \\
\hline A.65 & 5,3 & 2 Lantai & 2 Lantai & 46,64 & 29,15 & 37,50 \\
\hline
\end{tabular}




\begin{tabular}{ccccccc}
\hline A.66 & 3,1 & 2 Lantai & 2 Lantai & 28,21 & 16,74 & 40,66 \\
\hline A.67 & 3,3 & 2 Lantai & 2 Lantai & 31,35 & 19,14 & 38,95 \\
\hline A.68 & 4,1 & 2 Lantai & 2 Lantai & 38,95 & 28,7 & 26,32 \\
\hline A.69 & 5,4 & 1 Lantai & 2 Lantai & 34,02 & 26,46 & 22,22 \\
\hline A.70 & 4,7 & 1 Lantai & 2 Lantai & 30,08 & 30,08 & 0,00 \\
\hline A.71 & 6,8 & 2 Lantai & 2 Lantai & 91,12 & 73,44 & 19,40 \\
\hline A.72 & 6,8 & 2 Lantai & 2 Lantai & 95,88 & 81,6 & 14,89 \\
\hline
\end{tabular}

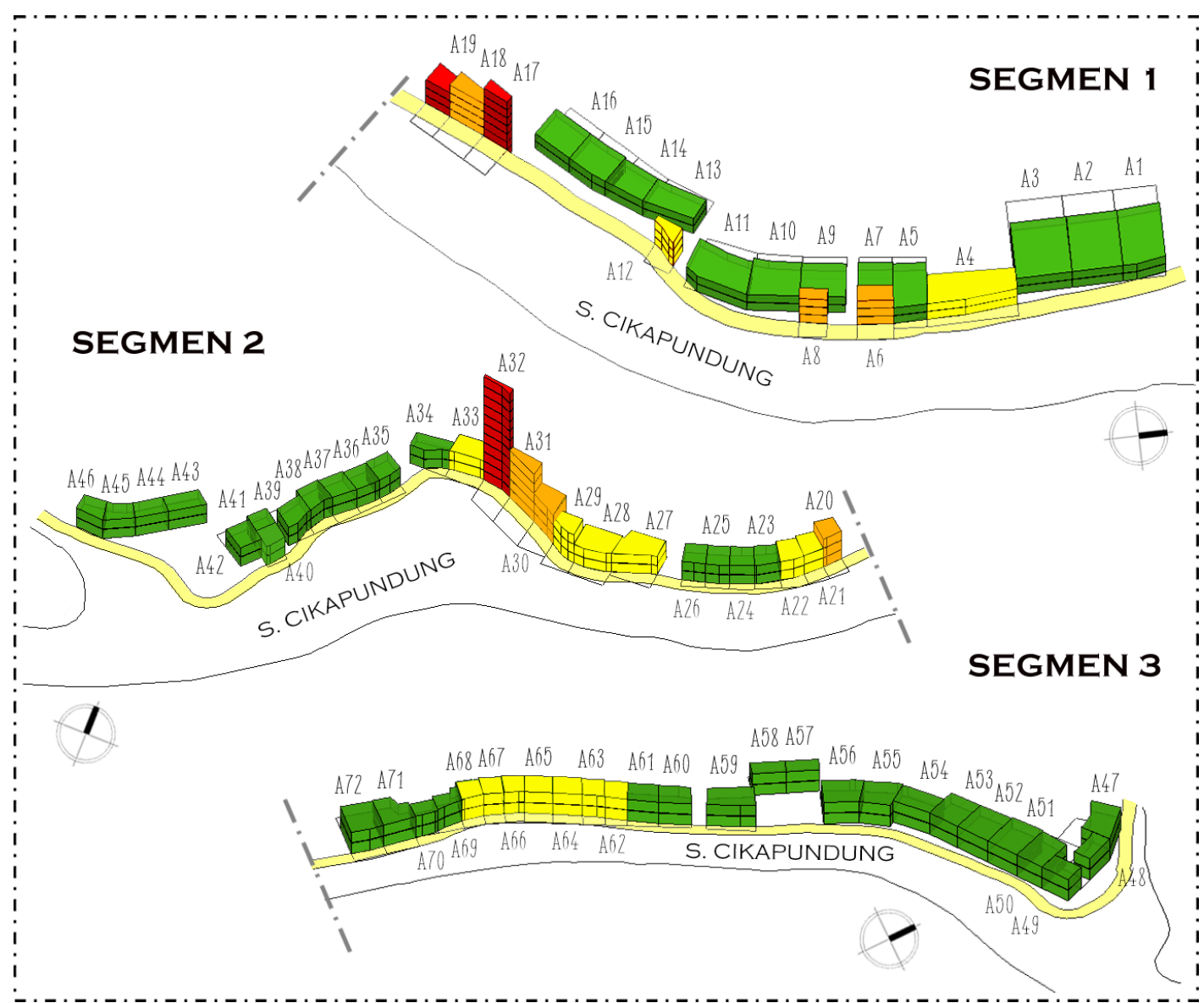

Gambar 5 : Penggambaran Segmen Hasil Simulasi Kampung Siliwangi

Hasil simulasi menunjukkan terdapat 9 dari 72 tapak, setelah aplikasi peraturan mengalami kehilangan lebih dari 50\% luasannya, ditandai dengan warna jingga dan merah. Namun tidak semua kavling yang kehilangan banyak luasan berada pada posisi tidak layak huni yaitu luasan di bawah $21 \mathrm{~m}^{2}$ sebagai asumsi tapak hunian minimum. Seperti kavling A30 dan A31 yang memiliki luas awal cukup besar, setelah aplikasi regulasi dan terpotong oleh garis sempadan sungai menghasilkan luasan tidak kurang dari $21 \mathrm{~m}^{2}$ sehingga masih sesuai standar layak huni. Solusi pada kasus seperti ini adalah dengan penambahan jumlah lantai bangunan untuk optimalisasi KDB dan KLB.

Untuk kavling dengan luasan hasil simulasi di bawah $21 \mathrm{~m}^{2}$ adalah A6, A8, A12, A17, A18, A19, A20, A32, A40, A66, A67. Dari 11 kavling ini tidak semua mengalami kehilangan luasan lebih dari 50\% (warna jingga dan merah). Hal ini disebabkan pada awalnya kavling eksisting tidak memiliki luasan yang terlalu besar. Setelah aplikasi peraturan, luasannya berkurang, panjang dan lebar kavling semakin mengecil dan tidak sesuai standar bangunan layak huni. Kasus ini terlihat pada kavling A12, A40, A66, A67. 
Tabel 3 : Hasil Simulasi Jumlah Unit dan Persentase Kampung Siliwangi

\begin{tabular}{clcc}
\hline No. & Warna Hasil Simulasi & Jumlah (Unit) & Persentase (\%) \\
\hline 1. & $0.00-24.99 \%$ (hijau) & 48 & $66,67 \%$ \\
2. & $25.00-49.99 \%$ (kuning) & 15 & $20,83 \%$ \\
3. & $50.00-74.99 \%$ (jingga) & 6 & $8,33 \%$ \\
4. & $75.00-100.00 \%($ merah) & 3 & $4,17 \%$ \\
\hline \multicolumn{2}{c}{ Total } & 72 & $100 \%$ \\
\hline
\end{tabular}

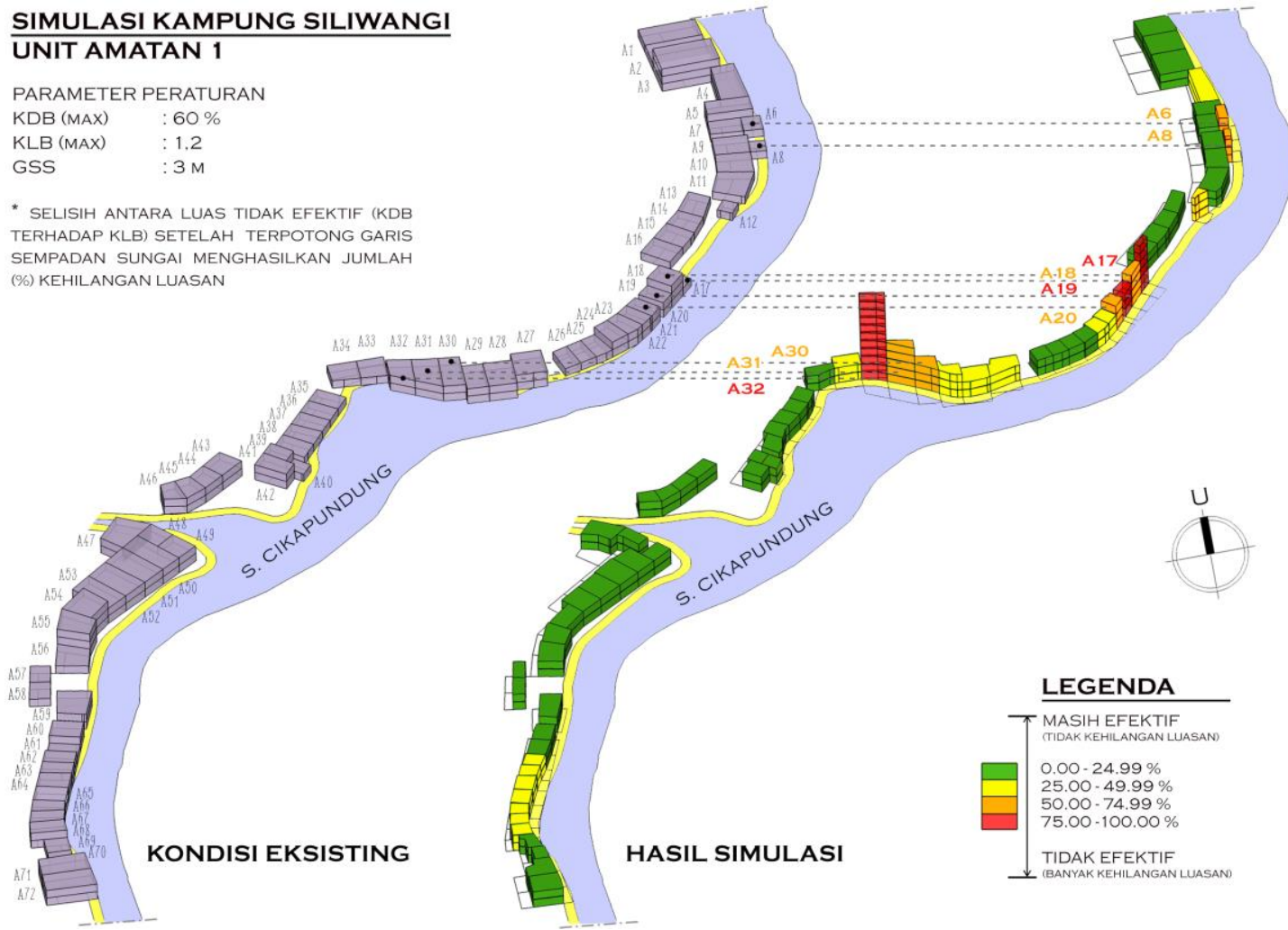

Gambar 6 : Kondisi Eksisting (Kiri) ; Hasil Proses Simulasi (Kanan)

Terdapat lebih banyak kavling pada Kampung Siliwangi yang masih dapat dipertahankan setelah penerapan regulasi, dengan solusi penambahan jumlah lantai bangunan disesuaikan dengan ketentuan besar KDB dan KLB. Lebar muka bangunan pada objek studi bervariasi antara 3-14,5 $\mathrm{m}^{2}$. Lebar sempit seperti pada kasus A63 yaitu 3,8 $\mathrm{m}^{2}$, setelah simulasi tidak membuat bangunan kehilangan banyak luasannya karena diimbangi dengan sisi dalam kavling setelah terpotong garis sempadan sungai 3 meter pun masih dapat mencapai luas tapak hunian minimum.

\section{DISKUSI / PEMBAHASAN}

Hasil simulasi memperlihatkan kondisi ideal permukiman Kampung Siliwangi yang sesuai dengan peraturan. Namun, sebelum diputuskan untuk ditindaklanjuti misalnya seperti penggabungan atau pemindahan lahan, simulasi parametrik digunakan untuk menggambarkan bangunan mana saja yang masih dapat tetap berdiri pada kawasan saat ini dengan memundurkan atau memotong bangunan namun tetap dapat memenuhi standar hunian 
minimum layak huni, serta bangunan mana yang tidak dapat tetap berdiri karena telah melanggar peraturan. Tahap selanjutnya dapat ditindaklanjuti dengan pengembangan peraturan atau solusi lain untuk penataan kawasan.

Proses simulasi dengan bantuan software Rhinoceros Grasshopper, membantu memprediksi dan memberikan gambaran kawasan Kampung Siliwangi di tepi sungai yang sesuai dengan aturan yang berlaku. Hasil simulasi menunjukkan peraturan yang membentuk kawasan secara signifikan adalah garis sempadan sungai dengan lebar 3 meter. Keteraturan muka bangunan terhadap sungai membentuk konfigurasi ruang yang seimbang (nyaman dan aman). Jalur inspeksi bertujuan untuk mencegah terjadinya erosi dan menjaga hunian dari sungai.

Terlihat bahwa hasil simulasi pada Kampung Siliwangi menghasilkan bangunan 2-3 lantai. Fluktuasi perbedaan ketinggian bangunan ini berkaitan dengan luas tapak awal (eksisting) dan aplikasi KLB maksimum. Terdapat beberapa kasus yang menjadikan bangunan harus memiliki jumlah lebih dari 4 lantai dengan luasan yang sempit. Hasilnya bangunan tidak dapat dihuni secara benar sesuai standar hunian minimum karena panjang dan lebarnya terlalu kecil, bangunannya pun terlihat 'pipih'. Kasus-kasus dengan ketinggian bangunan yang menghasilkan jumlah lantai banyak ini tidak dimungkinkan untuk dibangun atau berada pada tapak sekarang ini, perlu adanya solusi seperti relokasi atau penggabungan lahan.

\section{KESIMPULAN}

Simulasi parametris yang dilakukan pada Kampung Siliwangi menunjukkan bahwa ada beberapa kecenderungan yang mempengaruhi tingkat efektivitas pemanfaatan lahan dikaitkan dengan pencapaian luas lantai efektif, yaitu :

a. Tapak-tapak dengan rentang persentase kehilangan luas bangunan antara 0.00 \%-24.99\% (hijau) menghasilkan luas lantai hasil simulasi yang efektif yakni mencapai luas tapak hunian minimum $21 \mathrm{~m}^{2}$. Hal lain terjadi pada kasus tapak yang luas eksistingnya kecil, setelah aplikasi peraturan luasannya semakin berkurang, panjang dan lebar kavling semakin mengecil. Walaupun hanya kehilangan sedikit luasannya, tetap berada di bawah standar minimum sejak luasan awal.

b. Tapak-tapak dengan rentang persentase kehilangan luas bangunan antara 25.00 \%-49.99 $\%$ (kuning) sebagian masih aman dengan bentuk eksistingnya dan dengan jumlah lantai yang sama, hanya perlu dimundurkan sedikit akibat peraturan garis sempadan sungai. Sebagian lainnya, perlu dilakukan penambahan jumlah lantai bangunan untuk optimalisasi KLB.

c. Tapak-tapak dengan rentang persentase kehilangan luas bangunan antara 50.00 \%-74.99 $\%$ (jingga) mengakibatkan sebagian bangunan tidak dapat memenuhi standar hunian minimum. Sebagian lainnya dapat tetap menghasilkan luas bangunan di atas $21 \mathrm{~m}^{2}$ karena memiliki luas awal yang cukup besar dan setelah aplikasi regulasi dan terpotong garis sempadan sungai 3 meter, luasannya masih sesuai standar layak huni. Solusi pada kasus seperti ini adalah dengan penambahan jumlah lantai bangunan untuk optimalisasi KDB dan KLB.

d. Tapak-tapak dengan rentang persentase kehilangan luas bangunan antara 75.00 \%-100.00 $\%$ (merah) selalu menghasilkan luas di bawah standar minimum yang mengakibatkan bangunan memiliki luas yang sangat kecil dan pada dasarnya tidak layak huni karena tidak dapat dibangun. Solusi penambahan jumlah lantai dengan optimalisasi KLB pun tidak dapat dipergunakan karena tapaknya terlalu kecil. 
Setelah peraturan diterapkan, masih banyak bangunan yang masih ideal untuk terbangun dan dihuni, sesuai dengan ketentuan pada kawasan yaitu KDB maksimum $=60 \%$, KLB maksimum $=1.2$, dan garis sempadan sungai 3 meter. Proses simulasi dua dimensi maupun tiga dimensi memperlihatkan bangunan yang paling ideal pada Kampung Siliwangi adalah hunian 2 lantai dengan luas hunian minimum $21 \mathrm{~m}^{2}$. Apabila hasil simulasi menunjukan massa bangunan terlalu kecil atau bahkan memerlukan penambahan jumlah lantai yang banyak, maka seharusnya bangunan tersebut tidak layak huni atau tidak ideal dan tidak sesuai standar peraturan pada kawasan.

Kasus seperti ini kemungkinan dapat terjadi karena sebuah keluarga berkembang, penambahan jumlah anggota keluarga, kebutuhan bertambah, mengakibatkan penambahan luasan hunian ke sampung atau belakang. Penambahan luas cenderung ke arah sungai, dengan dibangunnya bangunan semi permanen yang melebihi batas tepi sungai. Hal ini memerlukan solusi berupa penggabungan lahan atau pemindahan lahan (relokasi). Kasus pada penelitian ini dapat dijadikan pedoman Rencana Tata Bangunan dan Lingkungan (RTBL) untuk perencanaan kawasan permukiman tepi sungai yang akan datang dengan dibantu kajian atau penelitian lebih lanjut melihat beberapa aspek seperti aspek historis, demografis, sosial (perilaku masyarakat), dan ekonomi.

\section{DAFTAR PUSTAKA}

Dewi, Julia. (2016). Relasi Bentuk dan Dimensi Tapak dengan Regulasi Dalam Membentuk Ruang Fisik Koridor Komersial. Bandung : Disertasi Universitas Katolik Parahyangan.

Nirwantari, Made Sintia. (2009). Identifikasi Pengaruh Perilaku Spasial Terhadap Konfigurasi Kampung di Bantaran Sungai. Bandung : Tesis Program Magister Arsitektur Pascasarjana Universitas Katolik Parahyangan.

Peraturan Daerah Kota Bandung No. 10 Tahun 2015 Tentang Rencana Detail Tata Ruang Kota dan Peraturan Zonasi Kota Bandung Tahun 2015-2035.

Peraturan Daerah Kota Bandung No. 18 Tahun 2011 Tentang Rencana Tata Ruang Wilayah (RTRW) Kota Bandung Tahun 2011-2031.

Peraturan Menteri Pekerjaan Umum dan Perumahan Rakyat Republik Indonesia No. 28 Tahun 2015 Tentang Penetapan Garis Sempadan Sungai dan Garis Sempadan Danau.

Peraturan Pemerintah Republik Indonesia No. 36 Tahun 2005 Tentang Peraturan Pelaksanaan Undang-Undang No. 28 Tahun 2002 Tentang Bangunan Gedung.

Sastrawan, Alexander dan Rumiati Rosaline Tobing. (2010). Kajian Penataan Fisik Permukiman Kumuh Area Pinggir Sungai Cikapundung. Bandung : Lembaga Penelitian dan Pengabdian Kepada Masyarakat Universitas Katolik Parahyangan.

Shirvani, Hamid. (1985). The Urban Design Process. New York : Van Nostrand Reinhold Company.

Tobing, Rumiati Rosaline (2010). Identifikasi Kawasan Permukiman di Area Pinggir Sungai Cikapundung Bandung. Bandung : Lembaga Penelitian dan Pengabdian Kepada Masyarakat Universitas Katolik Parahyangan.

Tobing, Rumiati Rosaline, Julia Dewi, Prof. Dr. Ing. Uras Siahaan. (2015). Relasi Bentuk dan Dimensi Tapak dengan Regulasi dalam Membentuk Ruang Fisik Koridor Komersial. Bandung : Lembaga Penelitian dan Pengabdian Kepada Masyarakat Universitas Katolik Parahyangan. 